\title{
RANCANG BANGUN SISTEM PENGUKUR SUHU DAN KELEMBABAN TANAH BERBASIS KOMUNIKASI RADIO
}

\author{
Tubagus Darussalam ${ }^{1}$, Hapsoro Agung Nugroho ${ }^{2}$ \\ ${ }^{1}$ Stasiun Meteorologi Sultan Thaha, Badan Meteorologi Klimatologi Dan Geofisika \\ Jambi, Indonesia \\ ${ }^{2}$ Program Studi Instrumentasi-MKG, Sekolah Tinggi Meteorologi Klimatologi Dan Geofisika \\ Tangerang Selatan, Indonesia \\ e-mail: hapsoro.agung@bmkg.go.id
}

\begin{abstract}
Abstrak
Suhu tanah dan kelembaban tanah merupakan salah satu parameter iklim yang sangat penting pengaruhnya terhadap tanaman. Suhu tanah merupakan salah satu unsur dalam pengamatan agroklimat. Badan Meteorologi Klimatologi dan Geofisika (BMKG) dalam salah satu tugas pokok dan fungsinya adalah melakukan pegamatan suhu tanah.Pengamatan suhu tanah umumnya masih menggunakan peralatan konvensional seperti termometer tanah yang bersifat analog. Sistem pengukur suhu dan kelembaban tanah bertujuan untuk mempermudah pengamatan dan mendukung otomatisasi peralatan. Perancangan sistem menggunakan sensor SHT11, mikrokontroler ATMega 2560 sebagai pengolahan data, modul radio telemetri sebagai sistem komunikasi. Data tersimpan di SD Card dan ditampilkan di komputer. Hasil pengujian menunjukan pengukur suhu dan kelembaban tanah mampu bekerja dan menyimpan data secara otomatis serta dapat berkomunikasi sejauh 120 meter.
\end{abstract}

Kata kunci: suhu tanah, kelembaban tanah, sensor SHT11, radio telemetri

\begin{abstract}
Soil temperature and soil moisture is one of the very important climate parameters influence on plant. Soil temperature, which is one element in the observation of Agroclimatology. Indonesia Meteorology Climatology and Geophysics Agency (BMKG) in one of its main duties and functions is to observe the soil temperature. The observation of soil temperature is still made by using conventional equipment such as soil thermometer which is still an analog thermometer. The design is made of a temperature gauge and soil moisture which aims to facilitate observation and supporting automation equipment. The design systems of this research used a sensor SHT11, microcontroller ATMega 2560 as data processing, telemetry radio module as a communication system. The data stored to SDCard and displayed on a personal computer. The results of research showed that, soil moisture and temperature instrument is able to work and store data automatically and can communicate as far as 150 meters.
\end{abstract}

Keywords: soil temperature, soil moisture, SHT11 sensor, radio telemetry

\section{PENDAHULUAN}

Suhu tanah dan kelembaban tanah memiliki peranan yang penting untuk manajemen sumberdaya air seperti peringatan awal kekeringan dan penjadwalan irigasi. Suhu tanah merupakan hasil dari keseluruhan radiasi yang merupakan kombinasi emisi panjang gelombang dari aliran panas dalam tanah. Suhu tanah yang baik untuk pertumbuhan umbi adalah 14.9 sampai $17.7^{\circ} \mathrm{C}$. Menurut ( $\mathrm{Li}$ et al., 2013)suhu tanah berhubungan dengan proses penyerapan unsur hara oleh akar, fotosintesis dan respirasi.Kelembaban tanah adalah sumber air untuk atmosfer melalui proses yang mengarah ke evapotranspirasi dari darat, yang meliputi terutama transpirasi tanaman dan penguapan tanah kosong (Seneviratne et al., 2010).Badan Meteorologi Klimatologi Jurnal Sains dan Teknologi| 146 
dan Geofisika dalam tugas pokok dan fungsi salah satu kegiatan berkaitan iklim melakukan pengamatan suhu tanah(BMKG, 2016). Pengamatan suhu tanah dan kelembaban tanah pada saat ini secara umum menggunakan peralatan konvensional. Sistem yang akan dibangun berbasis digital, diharapkan dapat mempermudah pengamatan dan mengurangi kesalahan pembacaan. Selain itu jarak antara lokasi pengamatan dan gedung cukup jauh sehingga diperlukan jalur komunikasi data berbasis nirkabel.

Sistem akan menghasilkan data suhu dan kelembaban tanah pada kedalaman $5 \mathrm{~cm}, 10 \mathrm{~cm}, 20 \mathrm{~cm}, 50 \mathrm{~cm}$, dan $100 \mathrm{~cm}$. Hasil pengukuran akan disimpan di datalogger kemudian ditampilkan pada Liquid Crystal Display (LCD) 20x4 dan komputer menggunakan komunikasi radio telemetri. Data yang ditampilkan pada komputer akan disimpan,sehingga data dapat digunakan kembali jika suatu waktu dibutuhkan.

Beberapa penelitian telah dilakukan berkaitan pengukuran suhu tanah dan kelembaban tanah diantaranya adalah penelitian yang dilakukan (Santosa \& Budiyanta, 2009)yang berjudul Rancang Bangun Sensor Suhu Tanah dan Kelembaban Udara. Penelitian ini membahas tentang rancang bangun sensor suhu tanah dan kelembaban udara dengan sensor yang digunakan untuk suhu tnah yaitu LM35 dan kelembaban udara HIH3610. Penelitian selanjutnya oleh (Suhendri, Irawan, \& Rismawan, 2015)melakukan penelitianSistem Pengontrolan Kelembaban Tanah Pada Media Tanam Cabai Rawit Menggunakan Mikrokontroler ATMega16 Dengan Metode PD (Proportional dan Derivative). Penelitian ini membahas tentang sistem pengairan berdasarkan nilai kelembaban tanah dan suhu tanah.

Terdapat beberapa penelitian yang berkaitan terhadap pemanfaatan sensor SHT11 diantaranya penelitian yang dilakukan oleh (Putranto, Laksono, \& Nurdiyanto, 2009)dari Pusat Penelitian dan Pengembangan BMKG dengan judul Aplikasi Sensor SHT11 Pada Pengukuran Suhu Tanah. Penelitian ini membahas tentang prekursor gempa bumi skala besar menggunakan sensor SHT11 yang merupakan sensor suhu dan kelembaban.

SHT11 adalah sebuah single chip sensor suhu dan kelembaban relatif dengan multi modul sensor yang outputnya telah dikalibrasikan secara digital. Dibagian dalamnya terdapat kapasitif polimer sebagai elemen untuk sensor kelembaban relative dan sebuah pita regangan yang digunakan sebagai sensor temperatur. Kelebihan dari sensor ini adalah keluaran nilai dari kedua sensor digabungkan dan dihubungkan pada ADC 14 bit dan sebuah interface serial pada satu chip yang sama (Al, 2017). Bentuk fisik sensor temperatur dan kelembaban SHT11 ditunjukan oleh Gambar 1.

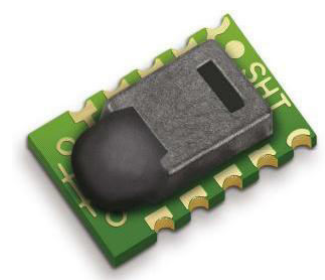

Gambar 1. Sensor SHT11 (sensirion .com)

Pengukuran kelembaban, elemen sensor dibuat dengan kapasitor. Dielektrik terbuat dari polimer yang menyerap atau melepaskan sejumlah air terhadap kelembaban relatif lingkungan sehingga menyebabakan perubahan nilai kapasitansi dari kapasitor. Perubahan kapasitansi ini kemudian diukur oleh sirkuit elektronik yang terdapat pada sensor.Pengukuran temperatur menggunakan sensor gap-type. perubahan temperatur menyebabkan perubahan nilai resistansi dari material yang digunakan. Nilai kelembaban dan temperatur langsung dikonversi menjadi data digital oleh ADC yang sudah terdapat pada sensor.

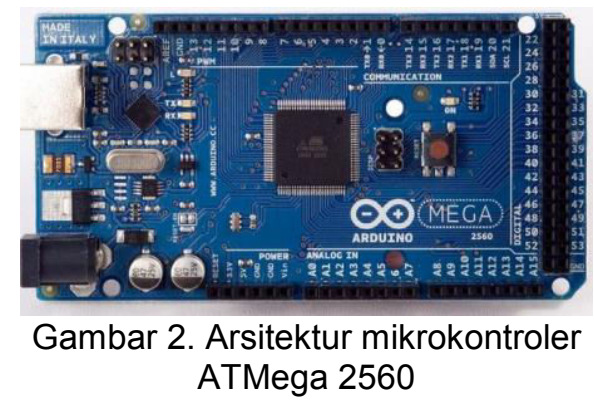

Jurnal Sains dan Teknologi| 147 
Mikrokontroler ATMega2560 adalah papanmikrokontroler berbasiskan ATMega2560. ATMega2560 memiliki 54 pin digital input dan output, sedangkan 15 pin lainnya digunakan sebagai output pulse width modulation, 16 pin sebagai input analog, dan 4 pin sebagai UART (port serial hardware), $16 \mathrm{MHz}$ kristal osilator, koneksi USB, power jack, ICSP header, dan tombol reset(Gopalakrishnan \& Hemalatha, 2017). Ini semua yang diperlukan untuk mendukung mikrokontroler. Arsitektur ATMega 2560 dapat dilihat pada Gambar 2.Dihubungkan ke komputer melalui kabel USB atau power dihubungkan dengan adaptor AC-DC atau baterai untuk mulai mengaktifkannya.

Modul Secure Digital Card seperti pada Gambar 3. untuk kartu penyimpan standar. Hal ini memungkinkan sistem untuk menambahkan penyimpanan dan data logging untuk penyimpanan data sistem, sehingga data-data yang dihasilkan dari sistem yang dibangun dapat secara otomatis tersimpan dalam memori.

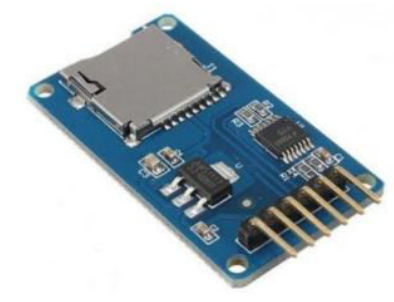

Gambar 3. Modul SDCard

Telemetri adalah sebuah teknologi yang memungkinkan pengukuran jarak jauh dan pelaporan informasi kepada perancang atau operator sistem. Modul Radio Telemetri 3DR 915Mhz merupakan modul yang memungkinkan untuk berkomunikasi jauh secara wireless menggunakan protokol data radio telemetri. Perangkat tersebut terdiri dari sepasang radio telemetri dengan komunikasi serial berupa transmitterreceiver dengan salah satu modul untuk digunakan pada perangkat komputer dan modul lainnya digunakan pada perangkat lainnya, seperti yang ditunjukan pada Gambar 4.(Hashim et al., 2013)menggunakan perangkat komunikasi radio frekuensi untuk sistem kontrol lampu lalu lintas.

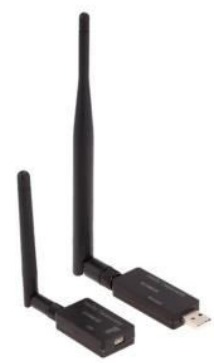

Gambar 4. Modul radio telemetri 3DR $915 \mathrm{MHz}$

\section{METODE}

Blok diagram sistem dapat diartikan bahwa semua pengumpulan serta proses pengolahan data dilakukan oleh mikrokontroler ATMega 2560. Sensor SHT11 memiliki pin output-input yang berbeda-beda, sesuai dengan kedalaman sensor tersebut. Sensor SHT 11 digunakan untuk input data suhu dan kelembaban tanah keluaran dari sensor adalah digital. Penanda waktu otomatis menggunakan Real Time Clock (RTC), untuk output dari sistem ini adalah dengan menggunakan LCD 20x4 dan komputer sebagai penampil output realtime dari masing-masing sensor, sedangkan untuk komunikasi menggunakan modul telemetri untuk menghubungkan ke komputer serta menggunakan modul SD Card sebagai penyimpanan data.

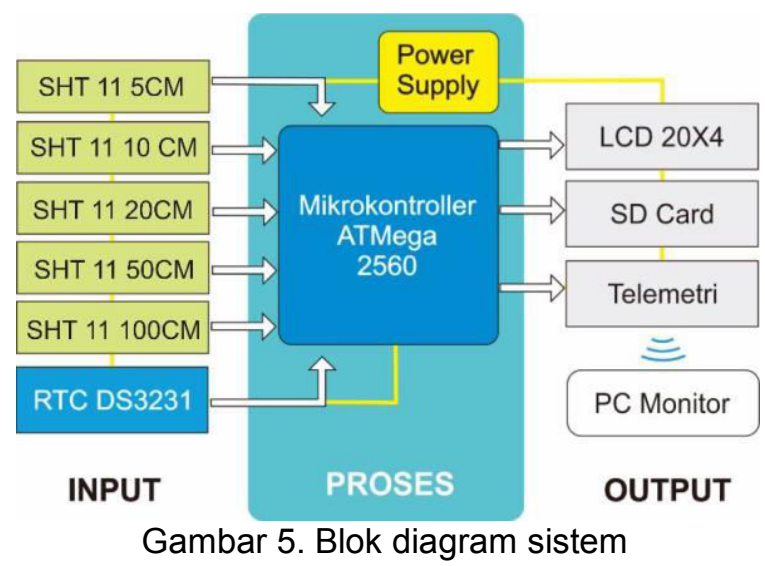

Fungsi bagian-bagian utama dari sistem yang ditunjukkan pada blok diagram diatas adalah sebagai berikut:

a. Mikrokontroler ATMega 2560 sebagai pusat pengolahan data, baik memproses data inputan yang masuk maupun mengatur kinerja dari komponen atau modul lainnya. 
b. Sensor SHT 11 memberikan input data suhu dan kelembaban tanah ke mikrokontroler

c. RTC sebagai tanda waktu secara real time

d. LCD 20x4 sebagai tampilan real time data

e. SDCard sebagai penyimpan data pada sistem

f. Telemetri sebagai komunikasi penghubung antara sistem dan komputer

g. Komputer untuk menampilkan output data pada layar monitor juga menyimpan data.

h. Power Supply sebagai sumber tegangan untuk komponen yang digunakan

Diagram alir sistem ini merupakan penggambaran sederhana dari cara kerja program yang dibangun pada perancangan sistem ini.
3. Membaca data waktu suhu dan kelembaban pada masing-masing kedalaman.

4. Mendapatkan data waktu suhu dan kelembaban pada masing-masing kedalaman.

5. Penyimpanan data di SDCard pada jam pengamatan yaitu pada jam yang telah ditentukan

6. Menampilkan data waktu suhu dan kelembaban pada LCD.

7. Mengirim data waktu suhu dan kelembaban menggunakan modul telemetri TX.

8. Menerima data waktu dan kelembaban menggunakan modul telemetri RX.

9. Penyimpanan data di PC pada jam pengamatan yaitu pada jam yang telah ditentukan.

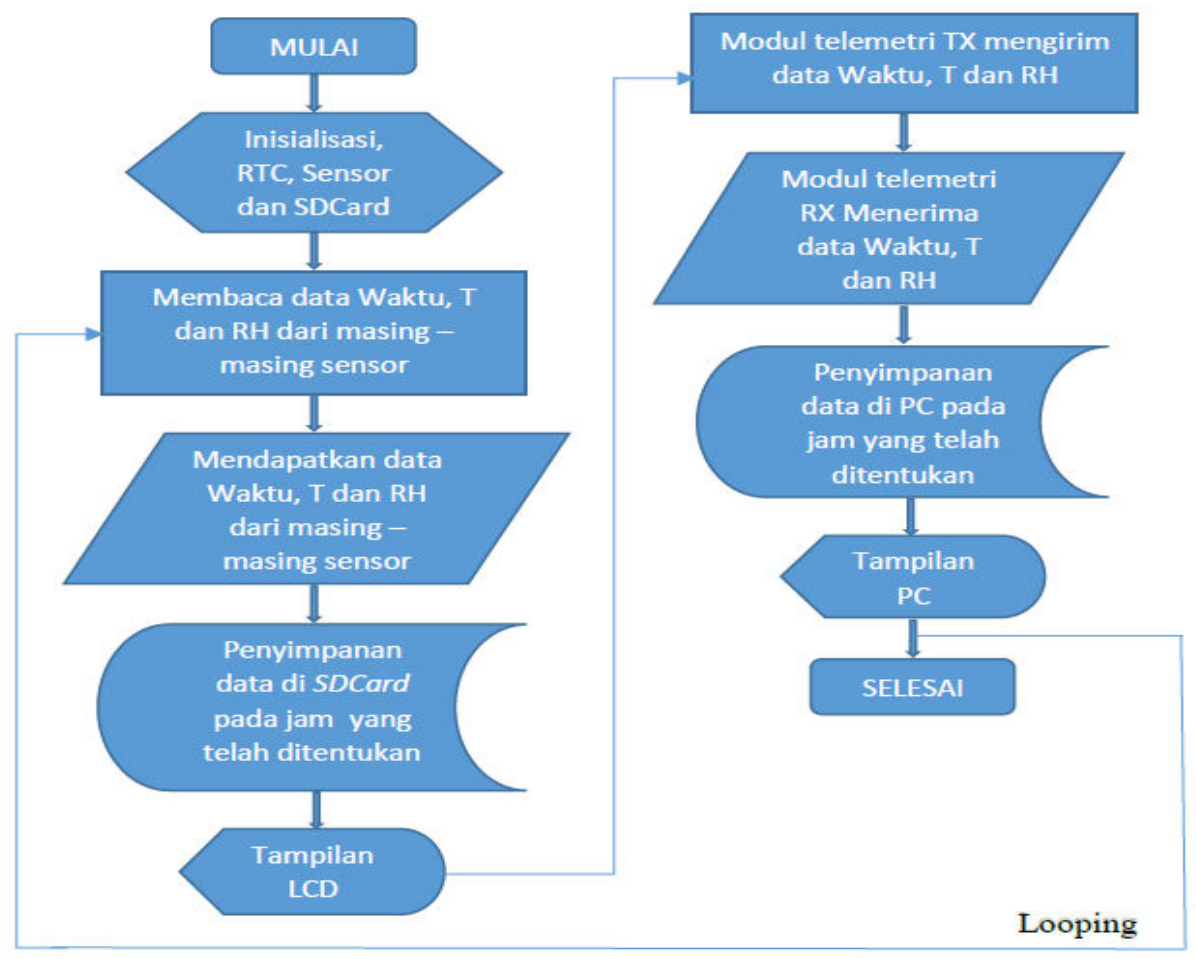

Gambar 6. Diagram alir sistem

Penjelasan flowchart pada Gambar 6. sebagai berikut :

1. Mulai merupakan awal dari suatu program

2. Melakukan inisialisasi Sensor, RTC, dan SDCard pada library pemrograman.
10. Menampilkan data di PC menggunakan program LabView melalui komunikasi telemetri dan akan melakukan pengulangan secara terus menerus.

11. Selesai.

Sistem akan otomatis memulai inisialisasi saat alat dihidupkan. Masingmasing sensor maupun modul pendukung 
yang telah dikoneksikan ke mikrokontroler, yaitu sensor SHT11, modul RTC, modul LCD serta modul SDCard. Setelah proses inisialisasi berhasil maka proses selanjutnya adalah proses pada mikrokontroler yaitu mengumpulkan dan mengolah data dari masing-masing sensor dan akan menyimpan hasil data pengolah ke dalam SDCard lalu menampilkan pada LCD. Setelah ditampilakan ke LCD, modul telemetri akan mengirim data yang akan disimpan dan ditampilkan ke PC menggunakan software LabView.

Skema rancangan sistem merupakan gambar rancangan komponen elektronika yang telah dirangkai sesuai fungsinya sebagai acuan dalam pembuatan alat pengukur suhu dan kelembaban tanah. Skema seperti ditunjukan pada Gambar 7.

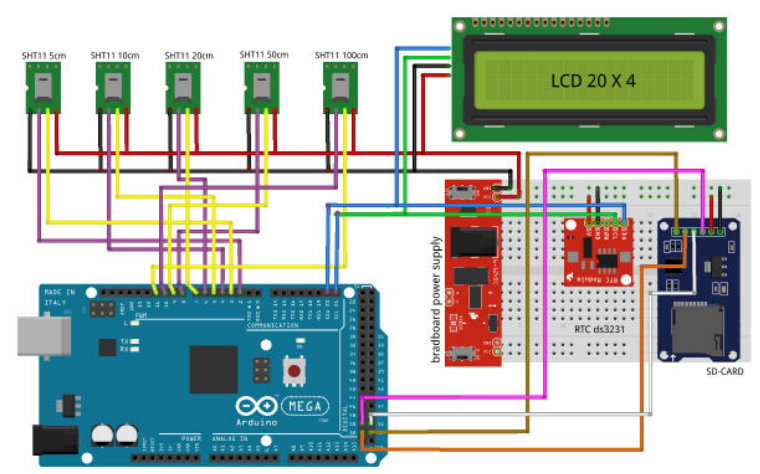

Gambar 7. Skema rancangan sistem

Konsep rancangan membahas tampilan fisik dari alat tersebut. Perancangan sistem ini terdiri dari beberapa komponen yaitu Mikrokontroler ATMega 2560, sensor SHT11, RTC, modul SDCard, LCD 20x4, modul telemetri, breadboard, serta breadboard power supply. Sensor SHT11 belum didesain kedap air sehingga perlu konstruksi khusus untuk mencegah terkena air tanpa harus memperlambat respon pengukuran suhu dan kelembaban.Pengujianpadarancangansiste muntukGambar 8. merupakan pembuatan perancangan casing logger, casing sensor SHT11 dan tiang penyangga logger. Casing yang akan digunakan terbuat dari bahan plastik, casing sensor SHT11 menggunakan bahan pipa PVC yang telah diberi lubang tujuannya untuk memperbaiki respon pengukuran karna bahan pipa PVC memiliki konduksivitas yang rendah, dan tiang penyangga logger yang terbuat dari besi dan pipa PVC.

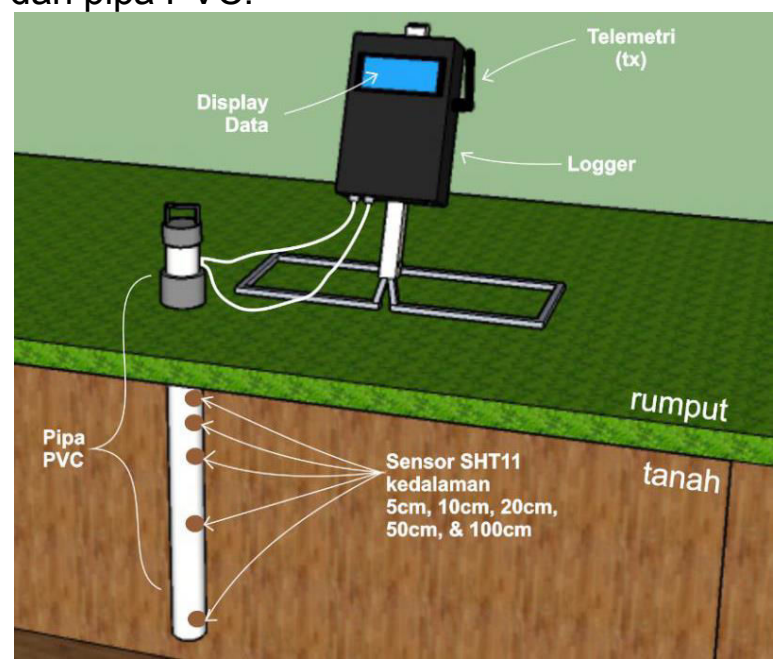

Gambar 8. Konsep rancangan sistem

Perancangan ini akan membahas mengenai perancangan perangkat lunak aplikasi yang akan tampil di PC. Perangkat lunak aplikasi ini nantinya akan menjadi antarmuka antara sistem dengan pengguna, sehingga dapat memudahkan pengguna dalam monitoring suhu dan kelembaban tanah. Perangkat lunak yang digunakan adalah LabView

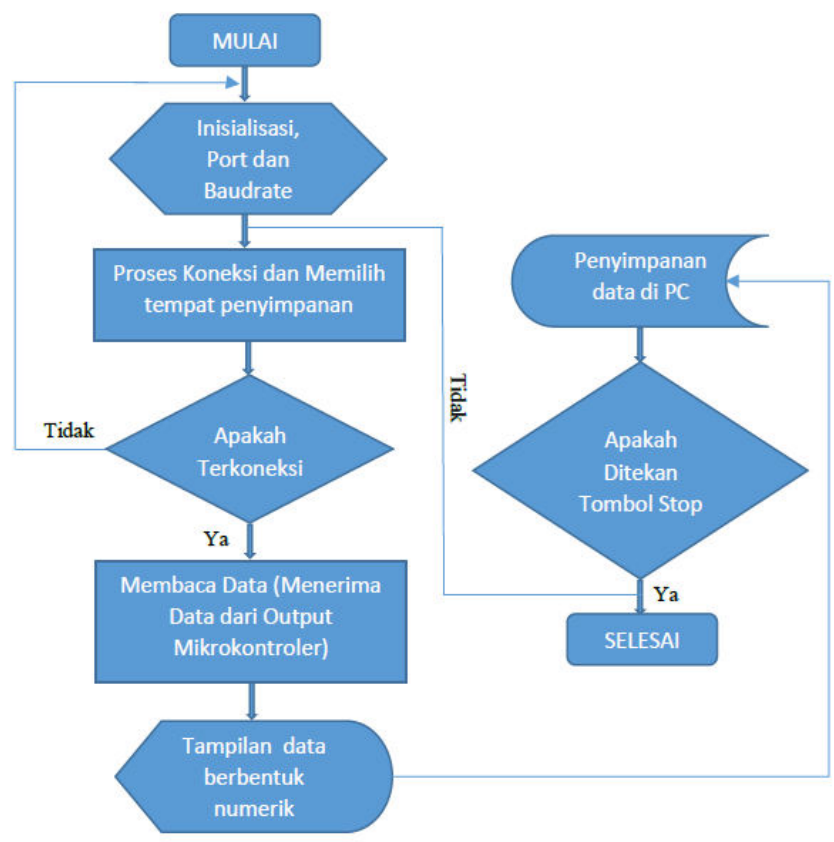

Gambar 9. Diagram alir perangkat lunak

Penjelasan diagram alir Gambar 9 sebagai berikut :

Jurnal Sains dan Teknologi| 150 
1. Mulai merupakan awal dari suatu program.

2. Melakukan inisialisasi port sesuai nomor port yang terdeteksi pada PC dan inisialisasi baudrate 57600bps.

3. Proses connect atau start untuk memulai program dan lokasi penyimpanan data otomatis langsung dengan format file format .txt.

4. Melakukan penerimaan data dari mikrokontroler.

5. Menampilkan data dalam bentuk numerik didalam LabView.

6. Data disimpan secara otomatis dalam bentuk file.txt pada folder.

7. Apabila tidak ditekan tombol stop maka akan kembali menerima data dari mikrokontroler namun ketika ditekan tombol stop maka sistem akan berhenti.

Konsep tampilan perangkat lunak akan menggunakan aplikasi LabView. Aplikasi tersebut berfungsi untuk menampilkan keluaran data suhu tanah dan kelembaban tanah secara real time dan data akan tersimpan secara otomatis. COM port dan baudrate berfungsi untuk menghubungkan aplikasi dengan perangkat keras yang telah ditentukan pada kolom yang tersedia, setelah itu mengisi kolom input data stasiun lalu pilih read. Port dan kolom input data stasiun yang dipilih dan di isi telah sesuai, maka suhu dan kelembaban tanah akan tampil dalam bentuk animasi termometer dan indikator numerikseperti yang ditunjukanpadaGambar 10.

\section{HASIL DAN PEMBAHASAN}

Kalibrasi untuk menentukan kebenaran nilai penunjukkan alat ukur dan bahan ukur dengan cara membandingkanterhadap standar ukur tertelusur yang bertujuan untuk mengetahui tingkat kedekatan hasi

Kegiatan kalibrasi dilakukan di Laboratorium Kalibrasi Peralatan Meteorologi BMKG Pusat, pada tanggal 29 Juli 2016 pukul 13.00 WIB sampai dengan selesai. Proses kalibrasi diawali

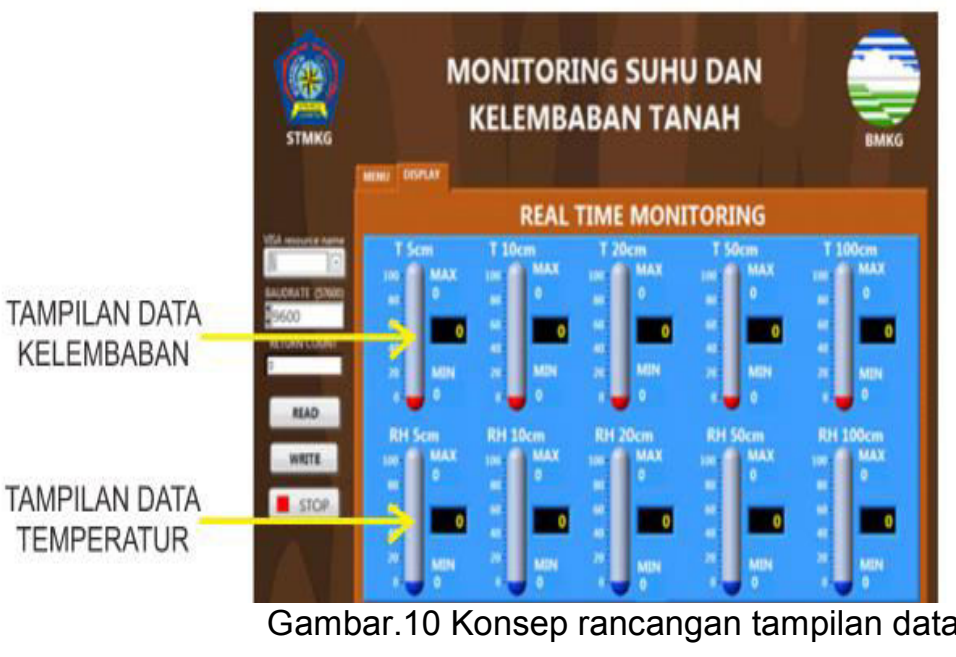

dengan menentukan beberapa set point sebagai titik sampel yaitu, $20^{\circ} \mathrm{C}, 30^{\circ} \mathrm{C}$ dan $40^{\circ} \mathrm{C}$. Sensor diletakan berdampingan dengan sensor standar, setelah itu dilakukan pengukuran berulang minimal empat kali pada setiap titik sampel.

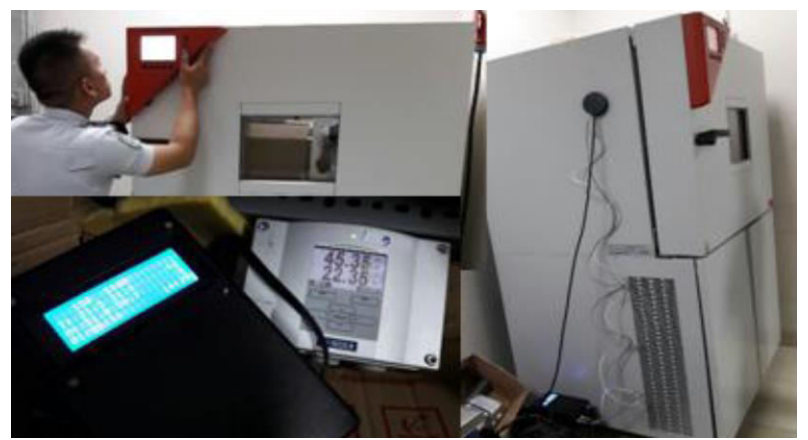

Gambar 11. Proses kalibrasi sensor SHT11

Gambar 11 menunjukan bahwa proses kalibrasi sedang berjalan. Data logger diletakkan berdampingan dengan display pembacaan suhu dan kelembaban standar untuk memudahkan dalam mencatat hasil pembacaan pada masingmasing sensor. Proses kalibrasi dilakukan dengan mencatat setiap suhu dan kelembaban pada

alat standard dan alat rancangan, sehingga dari hasil kalibrasi tersebut diperoleh nilai koreksi. Nilai koreksi rata-rata sensor untuk parameter suhu didapat $0,07^{\circ} \mathrm{C}$ dan $2,50 \%$ pada parameter kelembaban

Uji lapangan dilakukan dengan menempatkan sensor pada tanah yang telah diberi lubang. Uji lapangan bertujuan untuk mengetahui hasil pembacaan 
dengan cara membandingkan keluaran dari alat hasil rancangan dan keluaran dari alat standar yang digunakan sebagai pembanding. Perbandingan ini untuk mengetahui apakah keluaran dari alat hasil rancangan linier atau tidak dengan alat pembandingnya. Pada Gambar 12 dan 13 menunjukan hasil sistem perangkat keras serta tampilan antarmuka sistem.

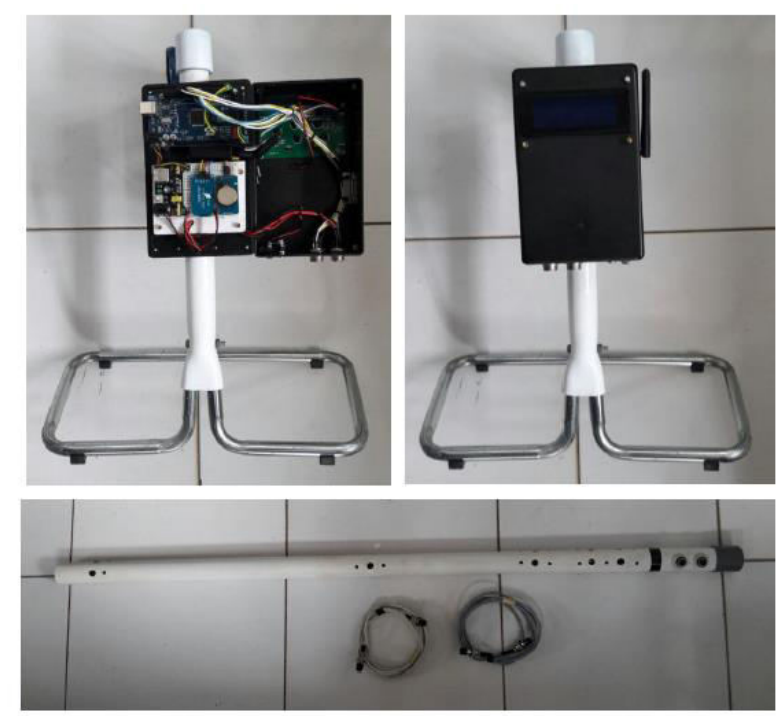

Gambar 12. Sistem perangkat keras

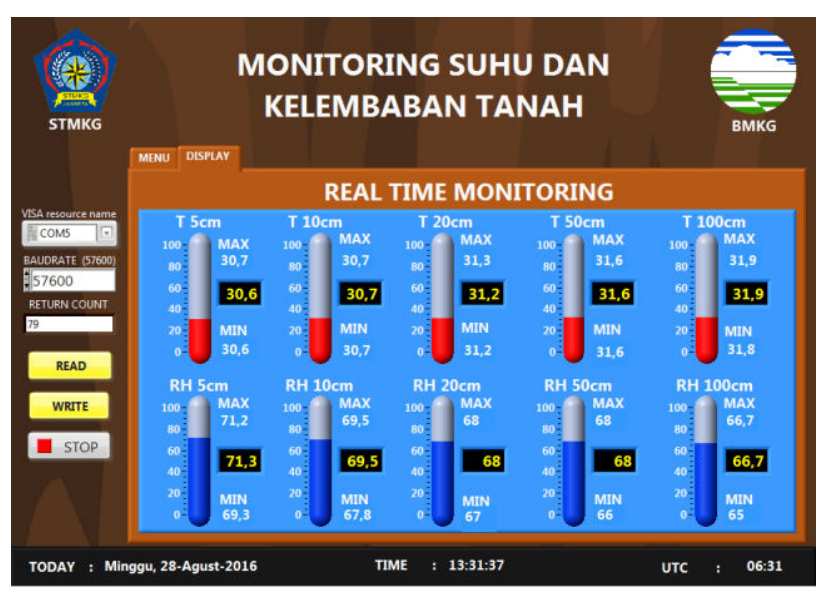

Gambar 13. Tampilan antarmuka data

Pengujian dilakukan di taman alat Stasiun Klimatologi Pondok Betung pada tanggal 21 Agustus 2016 pengamatan dan pengambilan data dilakukan dari pukul 02.00 WIB hingga 20.00 WIB dan pada tanggal 22 Agustus 2016 dari pukul 07.00 WIB hingga 20.00 WIB. Berikut adalah gambar peletakan alat monitoring suhu dan kelembaban tanah pada kedalaman $5 \mathrm{~cm}, 10 \mathrm{~cm}, 20 \mathrm{~cm}, 50 \mathrm{~cm}$, dan $100 \mathrm{~cm}$. Pada Gambar 14. terlihat bahwa penggunaan alat masih menggunakan termometer air raksa dan akan dibandingkan dengan sistem yang dirancang. Data suhu dan kelembaban tanah diambil setiap dua jam.

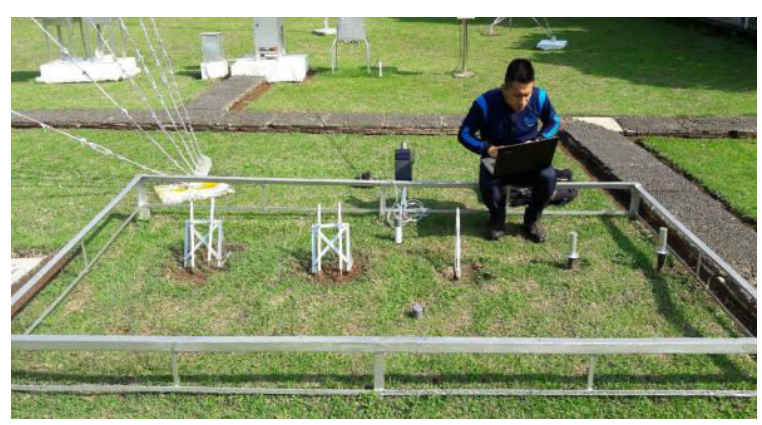

Gambar 14. Uji lapangan

Pada Gambar 15. perbandingan data suhu tanah dalam bentuk grafik. Grafik diatas menunjukkan perbedaan yang begitu signifikan dengan memperoleh nilai selisih sebesar $0,6^{\circ} \mathrm{C}$. Perbedaan yang cukup signifikan terjadi pada saat pengambilan data mulai pukul 13:00-19:00 WIB.

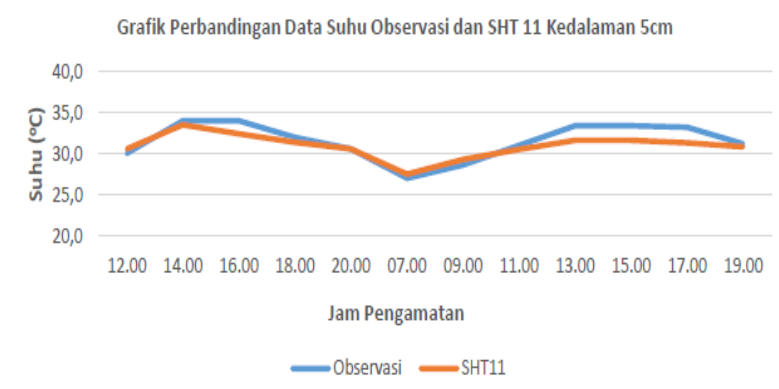

Gambar 15. Grafik perbandingan pengukuran suhu tanah kedalaman $5 \mathrm{~cm}$

Gambar 16. menunjukkan hasil pembacaan antara alat standar dan alat rancangan kurang baik tetapi nilai yang didapat pada pengukuran dan masih dalam nilai toleransi 


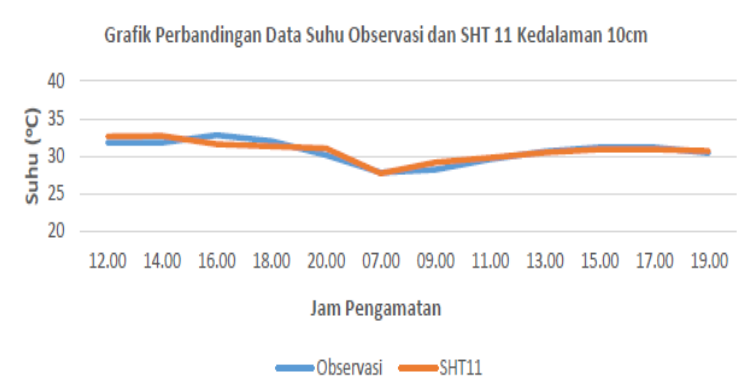

Gambar 16. Grafik perbandingan pengukuran suhu tanah kedalaman $10 \mathrm{~cm}$

Gambar 17. menunjukkan perbedaan yang begitu signifikan dengan memperoleh nilai selisih sebesar $-1,0^{\circ} \mathrm{C}$. Perbedaan yang cukup signifikan terjadi pada siang hari yaitu saat pengambilan data pukul 12:00-16:00 WIB, dimana suhu sensor SHT11 lebih tinggi dibanding sensor pembanding dan 07:00-09:00 WIB, dimana suhu sensor SHT11 lebih rendah dari pada suhu alat pembanding.

Grafik Perbandingan Data Suhu Observasi dan SHT 11 Kedalaman $20 \mathrm{~cm}$

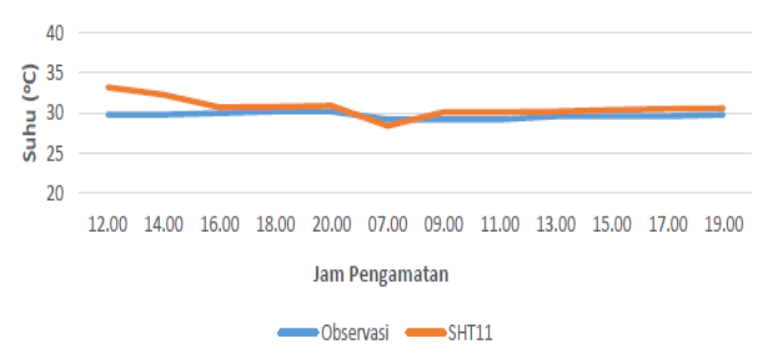

Gambar 17. Grafik perbandingan pengukuran suhu tanah kedalaman $20 \mathrm{~cm}$

Gambar 18 menunjukkan perbedaan yang begitu signifikan dengan memperoleh nilai selisih sebesar $-0,9^{\circ} \mathrm{C}$. Perbedaan yang cukup signifikan terjadi pada siang hari yaitu saat pengambilan data pukul 12:00-16:00 WIB, dimana suhu sensor SHT11 lebih tinggi dibanding sensor pembanding dan 07:00 - 09:00 WIB, dimana suhu sensor SHT11 lebih tinggi dari pada suhu alat pembanding.

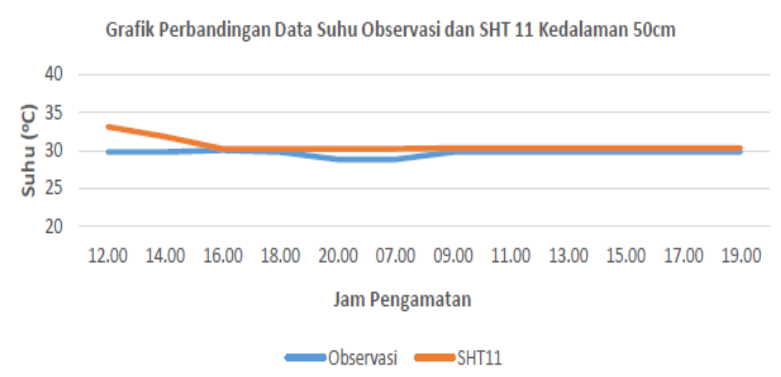

Gambar 18. Grafik perbandingan pengukuran suhu tanah kedalaman $50 \mathrm{~cm}$

Pada Gambar 19 perbedaan yang cukup signifikan terjadi pada siang hari yaitu saat pengambilan data pukul 12:0016:00 WIB, dimana suhusensor SHT11 lebih tinggi dibanding sensor pembanding dan 07:00-09:00 WIB, dimana suhu sensor SHT11 lebih rendah dari pada suhu alat pembanding.

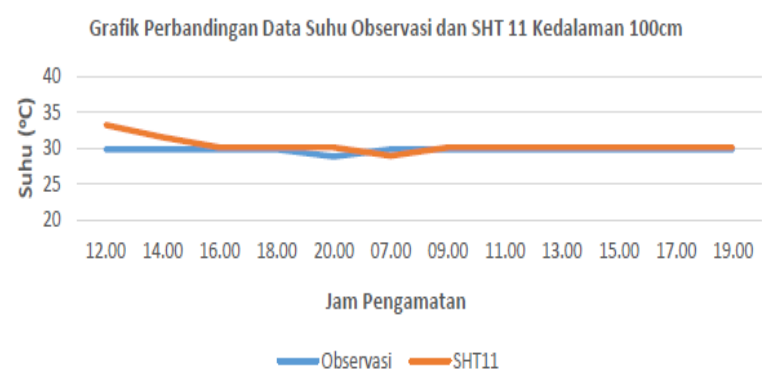

Gambar 19. Grafik perbandingan pengukuran suhu tanah kedalaman $100 \mathrm{~cm}$

Hasil pengujian kelembaban yang diamati, dapat dilihat perubahan kelembaban berkisar antara 58\% - $100 \%$ RH. Pada Gambar 20 dapat dilihat bahwa grafik kelembaban dari $100 \%$ pada pukul 01.20 (WIB) malam cenderung turun sampai dengan $58 \%$ pada jam 12.00 (WIB) siang dan mulai naik kembali pada pukul 16.00 (WIB) sore, grafik ini menunjukkan bahwa sensor kelembaban memberikan respon yang baik terhadap perubahan keadaan lingkungan. 


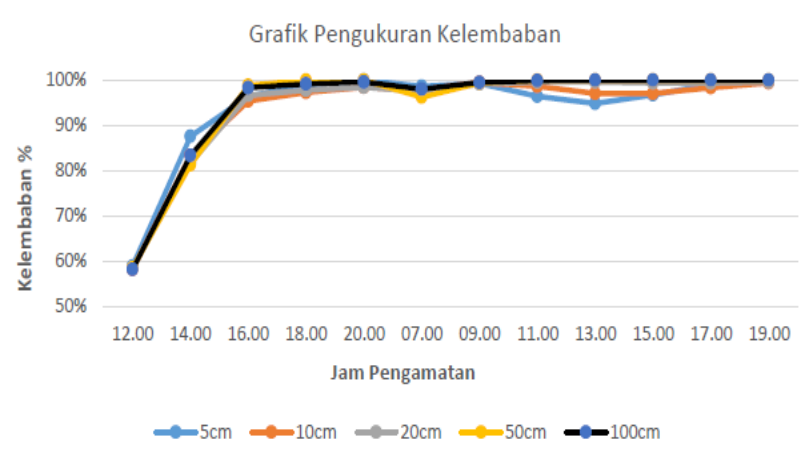

Gambar 20. Grafik pengukuran kelembaban

Pengujian komunikasi pada sistem bertujuan untuk mendapatkan hasil kerja sistem serta komunikasi nirkabel secara jarak jauh. Pengujian dilakukan dengan beberapa perbedaan jarak antara transmitter dan transceiver (TX-RX) dengan cara melihat pembacaan sensor dengan masing-masing output. Proses pengujian berlokasi di sepanjang jalan Camar-Pinguin Bintaro Sektor 3 pengujian dilakukan secara outdoor dan tanpa obstacle. Lokasi pengujian seperti yang ditunjukan pada Gambar 21.

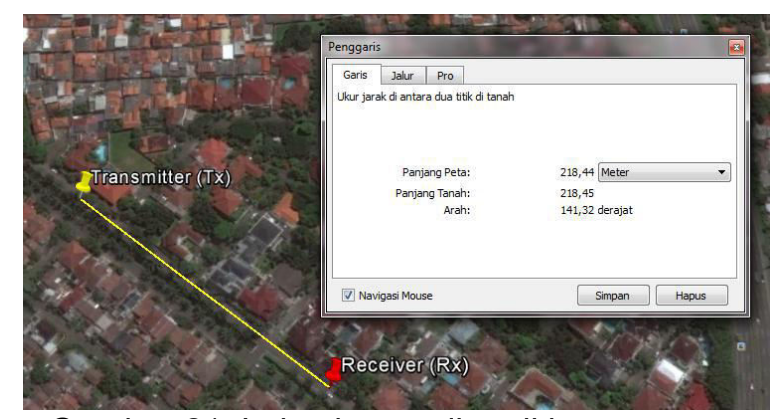

Gambar 21. Lokasi pengujian di luar ruangan

Hasil pengujian pada Tabel 1 dimana pada jarak $20 \mathrm{~m}$ sampai $40 \mathrm{~m}$ data dapat diterima dengan baik, sedangkan dari jarak $160 \mathrm{~m}$ sampai $220 \mathrm{~m}$ data dapat diterima tetapi membutuhkan delay yang cukup lama.

Tabel 1. Pengujian telemetri di luar ruangan

\begin{tabular}{cccc}
\hline $\begin{array}{c}\text { Jarak } \\
(\mathrm{m})\end{array}$ & $\begin{array}{c}\text { Delay } \\
(\text { detik })\end{array}$ & Komunikasi & $\begin{array}{c}\text { Kirim } \\
\text { Data }\end{array}$ \\
\hline 20 & 2 & Baik & Baik \\
40 & 2 & Baik & Baik \\
60 & 4 & Baik & Baik \\
80 & 4 & Baik & Baik \\
100 & 5 & Baik & Baik \\
120 & 6 & Baik & Baik \\
140 & 7 & Buruk & Buruk
\end{tabular}

\begin{tabular}{cccc}
160 & 8 & Buruk & Buruk \\
180 & 8 & Buruk & Buruk \\
200 & 9 & Buruk & Buruk \\
220 & 12 & Buruk & Buruk \\
\hline
\end{tabular}

Pengujian indoor dan terdapat obstacle dilakukan di Stasiun Klimatologi Pondok Betung. Berikut denah ruangan seperti pada Gambar 22.

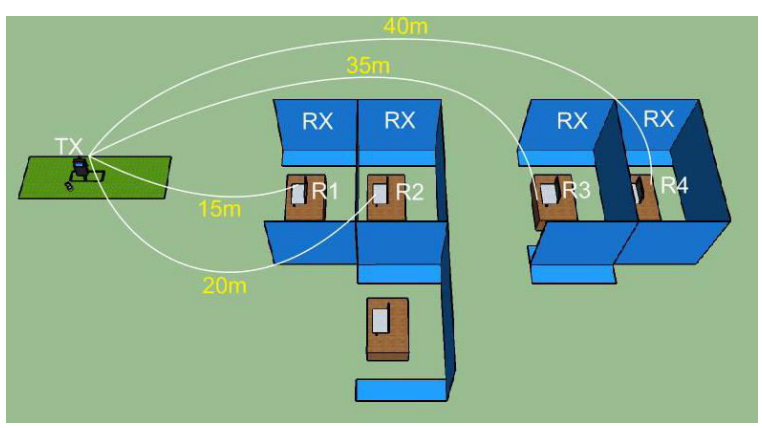

Gambar 22. Lokasi pengujian di dalam ruangan

Tabel 2 merupakan hasil pengujian indoor dimana pada jarak $15 \mathrm{~m}$ sampai jarak $20 \mathrm{~m}$ data dapat diterima dengan baik, pada jarak $35 \mathrm{~m}$ data dapat diterima meskipun mengalami delay selama 7 detik, sedangkan pada jarak $40 \mathrm{~m}$ data tidak dapat diterima karena terdapat penghalang yaitu dinding pembatas ruangan.

Tabel 2. Pengujian telemetri di dalam ruangan

\begin{tabular}{cccc}
\hline $\begin{array}{c}\text { Jarak } \\
(\mathrm{m})\end{array}$ & $\begin{array}{c}\text { Delay } \\
(\text { detik })\end{array}$ & Komunikasi & $\begin{array}{c}\text { Kirim } \\
\text { Data }\end{array}$ \\
\hline 15 & 2 & Baik & Baik \\
20 & 4 & Baik & Baik \\
35 & 7 & Buruk & Buruk \\
40 & - & Buruk & Loss \\
\hline
\end{tabular}

Gambar 23 merupakan penyimpanan otomatis pada aplikasiyang telah dirancang dalam format .txt. File tersebut akan tersimpan secara otomatis dalam folder yang telah ditentukan ketika aplikasi mulai dijalankan. 


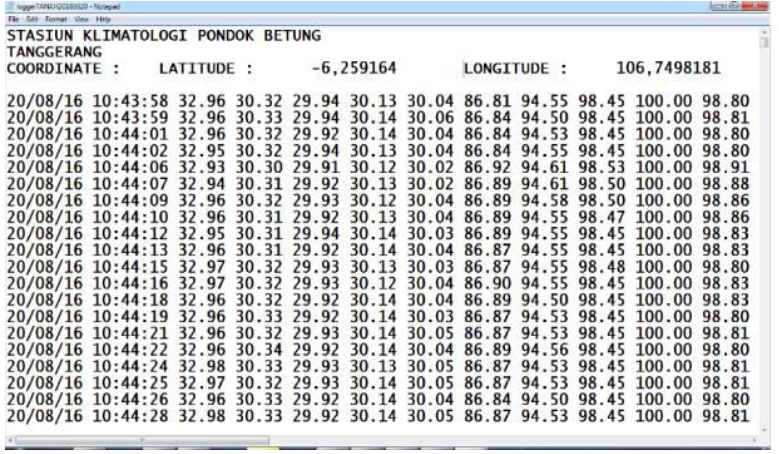

Gambar 23. Format data tersimpan

\section{SIMPULAN}

Perancangan sistem keseluruhan berjalan dengan baik, mulai dari hardware dan software melingkupi proses pengukuran, pengolahan, penyimpanan hingga komunikasi serta akuisisi data.Hasil pengujian alat pengukur suhu dan kelembaban tanah yang dilakukan di Laboraturium Kalibrasi BMKG Pusat, menghasilkan data koreksi rata-rata yang cukup baik yaitu $0,07{ }^{\circ} \mathrm{C}$ pada suhu dan $2,50 \%$ pada kelembaban. Berdasarkan data hasil kalibrasi alat pengukur suhu dan kelembaban tanah memenuhi toleransi yang ditentukan oleh World Meteorogical Organization (WMO, 2008) sebesar $\pm 0,2^{\circ} \mathrm{C}$. Hasil pengujian pengukuran suhu tanah menggunakan metode komparasi dengan alat observasi terdapat penyimpangan rata-rata sebesar kurang dari $1^{\circ} \mathrm{C}$. Komunikasi radio yang dilakukan pengujian di dalam maupun di luar ruangan bekerja dengan baik, dengan maksimum jangkauan $20 \mathrm{~m}$ untuk di dalam dan $120 \mathrm{~m}$ di luar ruangan.

Sistem pengukur suhu dan kelembaban tanah telah bekerja dengan baik, namun masih terdapat beberapa kekurangan. Adapun saran untukpengembangan berikutnya dari sistem ini yaitu penambahan sensor untuk melengkapi pengukuran suhu tanah yaitu suhu $0 \mathrm{~cm}$ dipermukaan tanah dan $5 \mathrm{~cm}$ diatas permukaan tanah. Kemudian Penambahan parameter untuk implementasi data untuk masa jenis tanaman. Terkait perancangan untuk data logger lebih dimaksimalkan agar kedap air.

\section{DAFTARPUSTAKA}

Al. (2017). Perencanaan Wireless Sensor Network ( WSN ) pada Sistem Monitoring Suhu. Jurnal Teknik Elektro ITP, 6(1), 9-19.

BMKG. Peraturan Kepala Badan Meteorologi Klimatologi Dan Geofisika No. 6 Tahun 2016 Tentang Pengamatan Dan Pengelolaan Data Iklim, Pub. L. No. NO. 6 Tahun 2016, 30 (2016). Indonesia: BMKG.

Gopalakrishnan, S., \& Hemalatha, V. (2017). An Embedded Based Monitoring and Distribution System for Water Supply in Urban Areas. International Journal of Engineering Science and Computing, 7(5), 1132611328.

Hashim, N. M. Z., Jaafar, A. S., Ali, N. A., Salahuddin, L., Mohamad, N. R., \& Ibrahim, M. A. (2013). Traffic Light Control System for Emergency Vehicles Using Radio Frequency. IOSR Journal of Engineering, 3(7), 2250-3021. Retrieved from www.iosrjen.org

Li, R., Hou, X., Jia, Z., Han, Q., Ren, X., \& Yang, B. (2013). Effects on Soil

Temperature, Moisture, and Maize Yield of Cultivation with Ridge and Furrow Mulching in the Rainfed Area of the Loess Plateau, China. Agricultural Water Management, 116, 101-109. https://doi.org/10.1016/j.agwat.2012.10 .001

Putranto, A. B., Laksono, B. I., \& Nurdiyanto, B. (2009). Aplikasi Sensor SHT11 Pada Pengukuran Suhu Tanah. Jurnal Meteorologi Dan Geofisika, 10(1), 66-72.

Santosa, C. E., \& Budiyanta, A. S. (2009). Rancang Bangun Sensor Suhu Tanah dan Kelembaban Udara. Jurnal Sains Dirgantara, 7(1), 201-213.

Seneviratne, S. I., Corti, T., Davin, E. L., Hirschi, M., Jaeger, E. B., Lehner, I., ... Teuling, A. J. (2010). Investigating Soil Moisture-Climate Interactions in a Changing Climate: A Review. EarthScience Reviews, 99(3-4), 125-161. https://doi.org/10.1016/j.earscirev.2010 
.02 .004

Suhendri, Irawan, B., \& Rismawan, T.

(2015). Sistem Pengontrolan

Kelembaban Tanah Pada Media

Tanam Cabai Rawit Menggunakan

Mikrokontroler ATMega16 Dengan

Metode PD (Proportional \& Derivative).

Jurnal Coding, 3(3), 11-22.

WMO. (2008). Guide to Meteorological

Instruments and Methods of

observation. Guide to Meteorological

Instruments and Methods of

Observation (Vol. I \& II).

https://doi.org/Guide to meteorological

instrument and observing practices 